\title{
小巟の気管・気管支粘液のアミラーゼ值
}

\author{
本蔵 高徳 ${ }^{1)}$, 雉本 忠市 ${ }^{1)}$, 伊藤 真樹 ${ }^{1)}$ \\ 土屋 康子'1), 小島 洋子2) \\ (1)国立小児病院呼吸器科) \\ (2)臨床検査科)
}

要旨：唾液流入が気管気管支内粘液の組成に及ぼす影響を知るため, 気管切開児, 長期気管内插管 児と一時的に気管内挿管をした患児を対象に気管気管支粘液のアミラーゼ值（ア值）を測定した。 長期気管挿管児の 1 例は唾液流入を常時認める患児である。

検体採取量とア值には相関なく唾液の直接的影響は否定的であった。常時気道確保児と一時気道 確保児のア值にも有意差はなく両者の唾液流入児は他の患児全体の值とは有意的に高いア值を示し たが，個々で比べるとさらに有意に高いア值を示すものがあり，ア值によって唾液流入は推定でき ても, その量は推定できないと考えられた。ミルク注入後には有意のア值上昇がみられ, 常時気道 確保児のア值は，患児に固有のパターンで日内変動を示した。気道内へのアミラーゼ分泌量が変動 することが考えられた。

\section{The Levels of Amilase in Tracheobronchial Secretion in Infants and Children}

\author{
T. Motokura' ${ }^{1)}$ C. Kijimoto ${ }^{1)}$, M. Ito ${ }^{1)}$, \\ Y. Tsuchiya ${ }^{1)}$, Y. Kojima ${ }^{2)}$ \\ ${ }^{1}$ National Children's Hospital Division of Respiratory Diseases \\ ${ }^{2)}$ Clinical Laboratory
}

We investigated the levels of amylase activity in tracheobronchial secretion (LATBSs) in the infants and children with tracheostomy or those intubated for months (group A) and those intubated transiently (group B) to know the effect of aspiration of saliva on the LATBS.

We detected amylase in all speciments of the secretion we investigated. The LATBSs were not correlated to the volume of the mucus aspirated from trachea or bronchus. There was no significant difference of the LATBSs between group A and group B. A girl who habitually developed massive intratracheal aspiration had significantly higher LATBSs than the whole data of the other patients. But her LATBSs were significantly lower than that of one infant who did not have massive aspiration. We got high LATBS in a specimen aspirated from a patient just after developing transient massive aspiration. It recovered to normal range after 5 days. Feeding of milk significantly increased the LATBSs in group A.

We found some circadian rhythms in the LATBSs of patients in group A. These patterns of the circadian rhyshms appeared to be characteristic to each patient.

Key words : アミラーゼ, 気管気管支粘液, 気管切開, 小児気道粘液分析, 唾液誤噁 
㾳の研究は50年以上前から行われており, 現 在では気管支粘液の物理的・化学的分析によっ て様々な病態を知る事ができる11。しかし小児 では気管支粘液あるいは痰の分析はほとんど行 われていないのが現状である。その原因として 喀痰を小児では得にくい事があげられる。小児 では検体を気管挿管児や気管切開児などから採 取しなければならない。しかしこれらの患児に はしばしば気管内唾液流入が伴う。また乳幼児 は嚥下障害あるいは誤嚥による肺疾患も少なく ない2)。すなわち小児では唾液混入による気管 支粘液成分の変化を十分検討しておく必要があ る。われわれはこの影響をみるため，小児の気 管支粘液のアミラーゼを, 唾液流入の比較的明 確な患児を含めて分析してみた。

\section{対象と方法}

気管切開児 3 名，常時気管挿管児 1 名の計 4 名を気道確保群とした。基礎疾患はそれぞれ気 管支軟化症 2 名, 嚥下障害 1 名, 気管狭窄 1 名 であり，平均年齢3.4 2 2.6（0.9〜 5.9）歳であ る。嚥下障害の 1 名は, 常時気管内に唾液流入 があり嬹下性肺炎を生じるため気管切開に至っ た患児である（症例 3 ）。

検査や手術目的で择管し吸引物の得られた男 子 3 名を対照群とした。基礎疾患はそれぞれ気 管支閉鎖症, 多発性囊胞, 気道異物（誤嬹）で あり，平均年齢 $2.3 \pm 0.8(1.10 \sim 3.0)$ 歳であっ た (表 1 参照)。

検体は気管分岐部付近まで滅菌吸引チューブ を挿入し可能なかぎり吸引して得られた粘液を 用いた。すぐ分析しない場合はー20度のディー プ・フリーザーに保存した。

アミラーゼ分析の方法は表 2 に示したように 検体に $\beta$-D-galactosidase $5 \mu 1$ を加え, $\mathrm{pH} 5.0$ のクエン酸 Buffer で液量を一定量に揃える。さ らに, Neuraminidase $20 \mu \mathrm{l}$ (0.04 units), Nacetylgalactosaminidase $10 \mu \mathrm{l}, \mathrm{N}$ - Acetylglucosaminidase $5 \mu 1$ を加え, 湯浴20分後 Mixing を行って粘性を低下させた。それぞれの検 体10 $\mu 1$ を $\mathrm{pH} 7.4$ のリン酸 Bufferで希釈して Mixing し FujiDrychem を用いてアミラーゼ を計測した。検体に加えた液量で計測値を補正 し，測定值とした。
表 1 対象患児 〈気道確保群〉

\begin{tabular}{|c|c|c|c|c|}
\hline 名前 & 年齢 & 性 & 気道確保方法 & 病 \\
\hline (1) N.O & $5.4 \mathrm{Y}$ & $\mathrm{F}$ & 気 切 & 気管,気管支軟化症 \\
\hline (2) N.K & $5.7 \mathrm{Y}$ & $\mathrm{M}$ & 気 & 気管,気管支軟化症 \\
\hline (3) A.K & $9 \mathrm{M}$ & $\mathrm{F}$ & 挿 & 鱮下障害 \\
\hline (4) H.N & $1.7 \mathrm{Y}$ & $\mathrm{M}$ & 気 & 声門下狭窄 \\
\hline
\end{tabular}

〈対 照 群〉

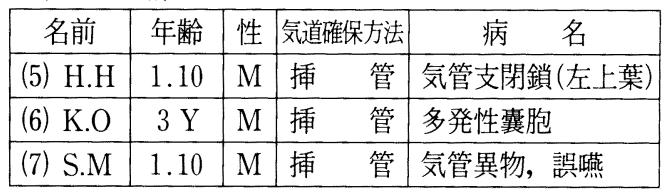

表 2 気道粘液アミラーゼ分析過程

(1) 検体に $\beta$-D-galactosidase $5 \mu \mathrm{l}$ を加える

(2) クエン酸 Buffer を加える

(あらかじめ予想している検体の量と同量)

(3) Neuraminidase $20 \mu 1$ を加える

(4) N-acetylgalactosaminidase $10 \mu 1$ を加える

(5) $\mathrm{N}$-acetylglucosaminidase $5 \mu \mathrm{l}$ を加える

(6) 湯浴 20 分

(7) Mixing (Vortex mixerにて)

(8)以上の処理を終った検体no $10 \mu \mathrm{l}$ はリン酸Buffer で希釈

(9) 希釈後 Mixing し Fuji drychem で計測

検定は測定值の対数を用いて行った。

\section{結 果}

対照も含め検査した51検体全例にアミラーゼ が多少とも検出された。得られた測定値は気道 確保群では最高 $294000 \mathrm{IU} / \mathrm{L}$, 最低86 IU/L, 平 均 $58006 \pm 72436 \mathrm{IU} / \mathrm{L}$ ，対照群は最高 2368000 $\mathrm{IU} / \mathrm{L}$, 最低771 IU/L, 平均 $62500 \pm 1163187 \mathrm{IU} /$ Lで，両者の間には有意差はみられなかった。

唾液流入が多いものは検体の採取量がその為 に増加することが考えられるが, 検体採取量と アミラーゼ值との間には統計学的に相関は認め られなかった（図 1)。

唾液流入が最大である症例 3 から得られた検 体のアミラーゼ值は最高 $113400 \mathrm{IU} / \mathrm{L}$ ，最低 $34000 \mathrm{IU} / \mathrm{L}$, 平均 $82476 \pm 32545 \mathrm{IU} / \mathrm{L}$ であり, これは他の気道確保群全体の值あるいはそれに 
対照群を加えた值および症例 1 , 症例 4 と比べ $5 \%$ の危険率で有意に高值といえた。しかし症 例 2 のアミラーゼ值と比較すると $0.1 \%$ の危険 率で有意に低值を示した。

測定值の標準偏差が非常に大きい理由は, 個々の患児のアミラーゼ值が一日の内でも 2 桁 に及ぶ変動を示したからである。すなわち IU/ Lで表わされるアミラーゼ測定值は対数的な変 動を示す。気道確保群の 2 例でその日内変動を 対数値でみてみると図 2 のようになる。すなわ ち数值は日によって全く異なるものの, 症例 1 では14時に最高值を示すというように，変動の

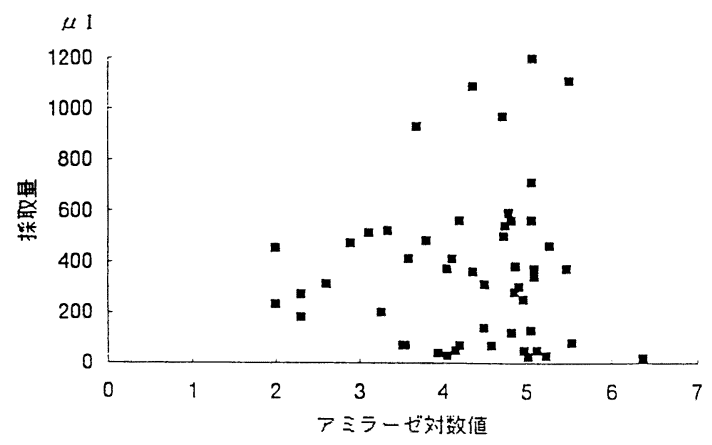

図 1 検体採取量とアミラーゼ值との関係

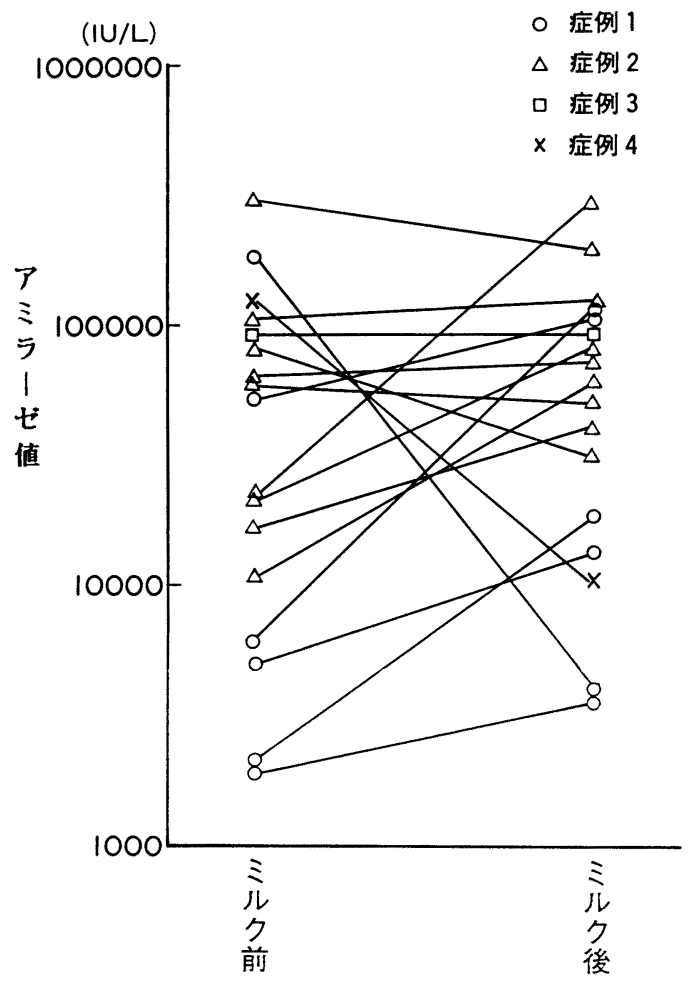

図 3 ミルク前後のアミラーゼ値

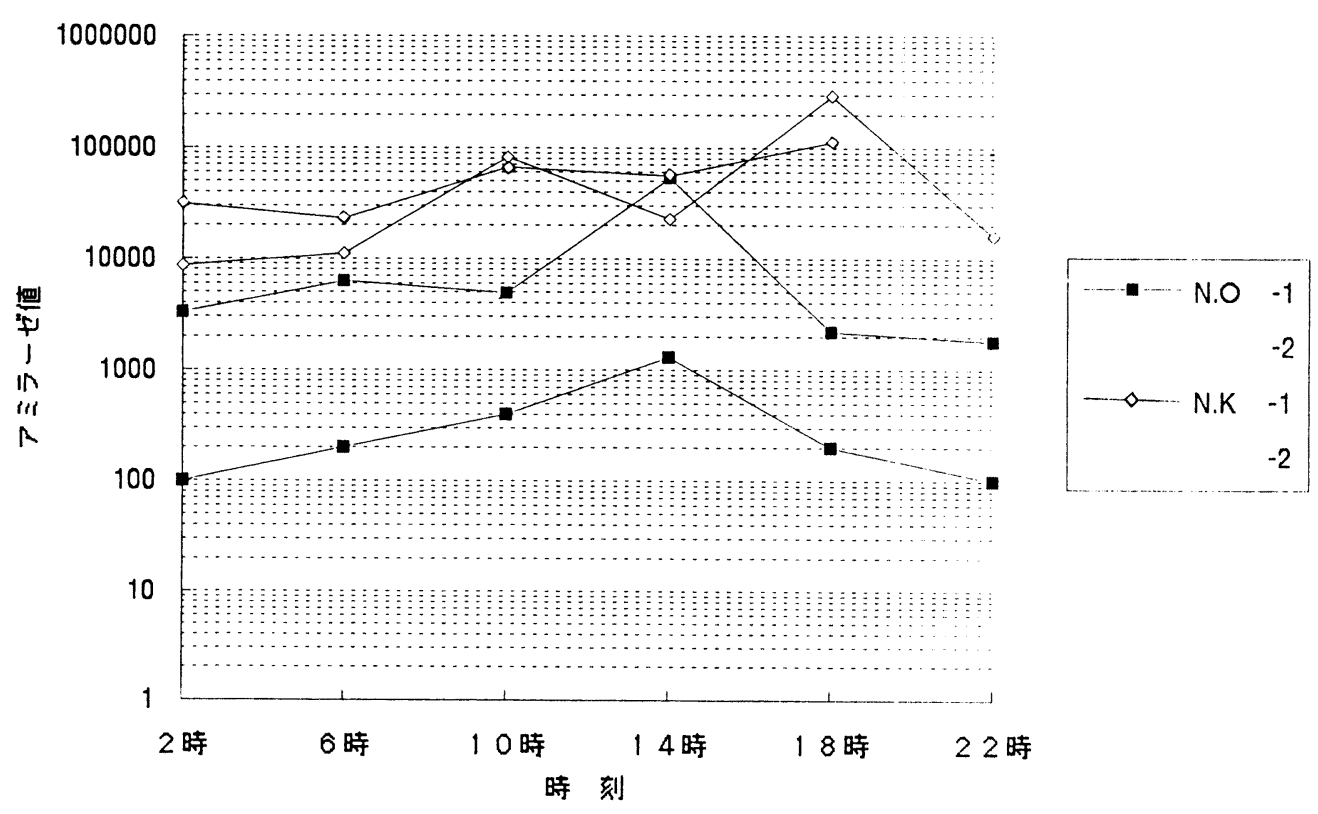

図 2 アミラーゼ値の日内変動 
パターンは個人毎にほぼ一定の型があるように 思われた。

ミルク注入前後で下気道内のアミラーゼ值を 比較してみると， $1 \%$ 以下の危険率で注入後の アミラーゼ值に上昇がみられた（図 3 )。

誤嚥が明らかであった患児のアミラーゼを同 時間のスポット值で比較すると直後は 14146 IU/L であったが， 5 日目には771 IU/L という 值で，明らかに低下が認められた。

\section{考案}

アミラーゼは気管支腺でも分泌され, 正常で も気管支粘液内に同定されるとされる ${ }^{3)}$ 。しか もそのアミラーゼの構造は唾液腺で分泌される ものと全く同じで化学的に区別不能であるとも いわれる4)。乳幼児ではとくに気管内唾液流入 との判別が問題である。対象児のうち最も唾液 流入が臨床的に多く認められる症例 3 は, 他の 対象児全体と比べると明らかにアミラーゼ值が 高かったが, 唾液流入が若干認められるが臨床 的にはあまり問題とならない症例 2 に比べると 有意に低值を示している。すなわち検体全体の アミラーゼ值によって, 唾液流入が多いことを 定性的に推定することは可能であるが, 流入の 量に相関するほどの精密性はなく, 得られたア ミラーゼ值から唾液流入を定量的には推定出来 ないことを示している。いいかえると常にアミ ラーゼの值が高いものは唾液の流入を想像させ るが，流入量の予測は全くできないということ である。

以上の事を念頭において, 気道確保群と対照 群のアミラーゼ値に有意差がないことを考える と，常時気管内插管をしている患児や気管切開 児と一過性に気管内烀管した患児とでは唾液流 入にあまり差がないことが想像される。すなわ ち, 気管内捙管で持ち込む程度の唾液が長期気 道確保児には流入していることが想像される。 ミルク注入後にアミラーゼ值は有意に上昇を示 しているが，ミルク注入後に唾液流入が増加す る徵候は臨床的に全く認められていない。気管 支腺からのアミラーゼの分泌が増加することが 原因と推定される。なお一回の誤嬹によって上 昇した下気道内のアミラーゼ值は少なくとも 5 日目には正常化することが示唆された。気管支
内の全粘液は健常人では24時間で置き換わると されており，対象患児に関してもこれょり早期 に正常に復していることが想像される。

この研究で分かった最も興味深い結果は気道 内のアミラーゼ值が日内変動を示し, その変動 パターンは患児毎に一定していることが示唆さ れたことである。日内変動が生じるためには, 唾液流入量に日内変動があるか，アミラーゼ濃 度そのものに日内変動があるかである。気道粘 液と同時に唾液のアミラーゼ濃度を測定してい ないので両者のアミラーゼ值の相関の有無は不 明であるが，唾液流入量の多少は気道粘液量の 多少に影響を与えるはずであることから考える と, 気道粘液採取量とアミラーゼ濃度は相関し ないため，唾液流入に日内変動があってアミラ 一ゼ濃度の日内変動を起こすことは否定的であ る。すなわち分泌されるアミラーゼ濃度に日内 変動があることが想像される。現在のところ血 清アミラーゼの日内変動は一般に健常者では明 らかではないとされている5。しかしその一方， ラットの唾液中のアミラーゼ值には13時や21時 にピークを示す日内リズムを示したという報告 もみられる6)。我々の結果からは気道粘液内の アミラーゼ值は日内変動を示すと考えたいが, 今後さらに症例を増やして検討する予定であ る。

\section{結 論}

1) 長期気管内捙管児，気管切開児（気道確 保群）と一時的気管内挿管児（対照群）の気管 粘液のアミラーゼ濃度を測定した。

2 ）全例にアミラーゼが多少とも検出され た。検体採取量とアミラーゼ値には相関はみら れなかった。気道確保群と対照群の值も全体と して比較すると有意差はなかった。

3 ）唾液流入が臨床的に著しい患児のアミラ 一ゼ值は，他の患児全体の值より有意に高値を 示したが，個々の患児の值に対してはその全て に有意的高值を示すほどではなかった。一回の 誤嬩によってアミラーゼは上昇したとしても少 なくとも5 日目には正常に復すると思えた。

4 ）アミラーゼ值は日内変動を示し, 患児毎 に一定のパターンを持っているようであった。

5 ）気道内アミラーゼ值はミルク注入後に有 
意の上昇を示した。

\section{文献}

1）長岡滋ほか：痰から何が学びとれるか．ライ フ・サイエンス出版，東京，1989.

2 ）伊藤真樹ほか：臙下障害が肺に及ぼす慢性的 影響の検討 (抄録)。日小呼誌， $3: 79,1992$.

3 ) V. Hayashi et al. : Amylase in human hungs and the female genital tract. Histohemis- try. $85: 491-496,1986$.

4) 佐野正明：気道液中のアミラーゼ，プロテア 一ゼ，ホスホリパーゼA活性に関する研究. 名市大医誌, $36 ： 417-430,1985$.

5 ）早川哲夫ほか：アミラーゼ。綜合臨牀．34： 1842-1844, 1985.

6 ）石川康子ほか：唾液腺アミラーゼ分泌におけ る日内リズムの形成機構. I . $\beta$-adrenoceptorの日内リズム (抄録). 歯基礎誌, 30 (補)：125, 1988. 